\title{
The range of olfactory familiarity between individuals in a population of bank voles
}

\author{
Edyta OWADOWSKA
}

Owadowska E. 1999. The range of olfactory familiarity between individuals in a population of bank voles. Acta Theriologica 44: 133-150.

The aim of the study was to test a hypothesis that small rodents in natural conditions are able to distinguish between the scents of neighbour $(\mathrm{N})$ and stranger $(\mathrm{S})$ individuals of conspecific. Experiments were carried out in a 100 -year-old alder forest of the association Circaeo-elongatae Alnetum (Koch. 1926), on a population of bank voles Clethrionomys glareolus (Schreber, 1780). Experiment I found higher capture rates in traps with the scent of $\mathrm{N}$ individuals $(n=35)$ and showed that the rodents could distinguish between N and S scents. Analysis of 90 sheets of Bristol board laid down in the forest in experiment II showed that rodents left significantly more traces of faeces and urine on sheets with the N scents. Experiment III showed that at distances of as much as $200 \mathrm{~m}$ from the place of origin of a donor there had been no decrease in the interest of other voles in its scent. Experiment IV increased the distance at which a fall-off in interest in the $\mathrm{N}$ scent was sought. As a result of 856 observations of the reactions of voles to the scents of donors originating at different distances, it was found that voles treated as $\mathrm{N}$ individuals those donors coming from distances of up to about $1000 \mathrm{~m}$. Analysis of 840 sheets of Bristol board with scents of donors originating between 200 and $1400 \mathrm{~m}$ away used in experiment $\mathrm{V}$ showed that those smelling of donors from 1200 and $1400 \mathrm{~m}$ away were visited significantly less often by the rodents than others. A distance of around $1000 \mathrm{~m}$ may thus be the threshold for a decline in the interest of rodents in the $\mathrm{N}$ scent.

Kampinos National Park, Tetmajera Str. 38, 05-080 Izabelin, Poland

Key words: Clethrionomys glareolus, the range, olfactory familiarity, scent of neighbour, scent of stranger

\section{Introduction}

The main factors defining the increase of a rodent population are recognized to be the manner in which the population uses space, as well as the social interrelationships between individuals established against the background of this space. The theories put forward by authors such as Christian (1950), Chitty (1958) and Bujalska (1970, 1985a, b), Kruczek (1997) assign an important role in population phenomena to direct aggressive contacts between individuals. However, more and more studies are drawing attention to the ubiquitous phenomenon of the avoidance of contacts with unknown individuals (strangers) (eg Andrzejewski and Olszewski 1963, Wilson 1975, Vestal and Hellack 1978, Gipps 1981). 
Since the phenomena of the mutual impacts of individuals play such an important role in the functioning of a population, while the use of vision by rodents in conditions of impaired visibility is very limited (Stoddart 1980), the key to greater understanding is the manner in which information is transmitted between individuals. The questions thus arising are as follows:

1. how is information emitted between individuals in different environments?

2. which senses help animals to read this information?

3. how far from the place of residence of a rodent is its smell known to other individuals?

In olfactory communication, information is conveyed by the secretions from various glands (Quay 1962, 1968, Griffiths and Kendall 1980a, b, Marchlewska-Koj et al. 1983, 1992, Lenington 1994), as well as by urine and faeces (Stoddart 1974, Marchlewska-Koj et al. 1983). The character of the scents of the latter are in turn influenced by the type of food available to rodents (Stoddart 1974, Ferkin et al. 1997) and a sexes of individuals (Kruczek 1994, Kapusta et al. 1996). The methods of conveying information by scent - which are probably a basis for social interactions between the individuals in a population - are still poorly-known and have been studied mainly in artificial conditions (terraria, aviaries, etc).

Observations of the behaviour of two individuals of the deer mouse Peromyscus maniculatus austerus (Healey 1967), showed that adult males react more aggressively to unknown individuals than to neighbours. This was later termed the "dear enemy phenomenon" by Wilson (1975). Laboratory studies by Vestal and Hellack (1978) on two deer mice Peromyscus species confirmed the existence of neighbour-stranger relationships between individuals. However, attempts to test this in the field have been few and far between. Among the important such cases are the studies by Rajska-Jurgiel (1976), on a population of C. glareolus. This research demonstrated the greater interest shown by voles in traps containing neighbours, as opposed to those with strangers.

Andrzejewski and Owadowska (1994) devised new method for transferring the individual scent of a vole to snap traps. They used pieces of polyurethane foam (hereafter "sponge"), put in glass jars in which rodents were placed subsequently and left for three hours without food - two times a day. The sponges so-prepared were placed in clean snap traps and used as bait in field experiments. It was discovered that a tested samples of a rodent was more attractive than a clean piece, or than standard food bait. Employing the same method of transferring rodent scent, Andrzejewski et al. (1997) demonstrated the equal attractiveness to $C$. glareolus caught in the field of the scents of this species and of A. sylvaticus.

The results of studies (eg Kołodziej et al. 1972, Wilson 1975, Rajska-Jurgiel 1976 and Vestal and Hellack 1978) show positive reactions in the field: direct and/or olfactory in relation to individuals living nearby (neighbours?), and the avoidance of contact with strangers. These findings raise questions as to whether such behaviour among rodents is more common than aggressive reactions in the conditions of natural populations. 
The aim of the study presented here was thus to verify the hypothesis that a population of bank voles Clethrionomys glareolus (Schreber, 1780) living in a natural environment is characterized by a phenomenon in which the scent of neighbour $(\mathrm{N})$ individuals of the same species is distinguished from that of strangers (S). In the event of this hypothesis being confirmed, the next aim was to determine, in the field, the distance up to which the scent of a donor is recognized by other individuals as that of a neighbour, and by definition also the distance beyond which the donor-individual is treated as a stranger.

\section{Study area}

The experiments were run in the western part $\left(52^{\circ} 20^{\prime} \mathrm{N}, 20^{\circ} 25^{\prime} \mathrm{E}\right)$ of Kampinos National Park near Warsaw, in 100-year-old alder forest of the association Carici elongatae-Alnetum (Koch. 1926). In connection with changing water relations affecting the entire Park, the association is being transformed in the direction of the association Circaeo-Alnetum (Oberd. 1953), with significant cover of nettles Urtica dioica L. in the undergrowth (Solon 1995). The drying-out of the forest floor has combined with the appearance of large amounts of herb vegetation to create very good living conditions for voles (Mazurkiewicz 1994), which find here an excellent food base, as well as a large number of places to live in the dense undergrowth (Pucek 1983). In this area the voles occurred at fairly constant high densities through all the years of study. Other rodent species accounted for between 1\% (1994) and 10\% (1996) of the individuals caught (Andrzejewski et al., in press), with the species noted including the yellow-necked mouse Apodemus flavicollis, which came in from the neighbouring Tilio-Carpinetum (Tracz 1962), as well as the wood mouse Apodemus sylvaticus, the striped field mouse A. agrarius, and the short-tailed vole Microtus agrestis.

\section{Methods and materials}

\section{Experiment I}

To check the attractiveness to voles of the scents of $\mathrm{N}$ individuals and those from another population (S), 5 lines of traps were laid out in the field at distances of about $100 \mathrm{~m}$ apart. Each line contained, in succession, 4 snap traps, 2 live traps and again 4 snap traps, and the distance between traps was $1 \mathrm{~m}$. On the first day, the two live traps on all lines were baited with oats, moist food (apple) and 6 pieces of sponge of dimensions $1 \times 1 \times 1 \mathrm{~cm}$. Following the capture of a rodent, these took on the scent of glandular secretions, urine and faeces. On the morning of the second day, the traps were checked, and those containing voles were supplied with more oats and moist food but otherwise left until the following day (to ensure a sufficiently strong scent on the sponge). Other species of rodent caught were released, and the traps emptied of oats, scraped of dried faeces and any other matter and closed. After a further day, all the voles were released following marking by clipping, and the traps were cleaned, rebaited and new pieces of sponge added to each (including those closed on the previous day). The traps were then set and the activities described above repeated. The "scented" pieces of sponge taken from the cleaned traps were treated as sources of the scent of neighbour $(\mathrm{N})$ individuals and were placed in every second snap trap of the two group of 4 . The remaining 4 traps along each line were provided with the same kind of sponge, but this time with the scent of 4 unfamiliar or "stranger" (S) voles (2 males and 2 females). These were selected at random from a group of 10 caught 40 kilometers from the study area a week before the start of the experiment. These were voles were kept together in the laboratory, in a terrarium, until the research ended. The scent deriving from these animals was obtained in the following way: the same food as used in the live traps was placed in a 2 -litre glass jar with a perforated covering, along with 30 pieces of sponge and 4 voles. The rodents 
were kept there for one day, after which they were returned to the terrarium and the pieces of sponge used in field captures as a source of the scent of stranger individuals.

The snap traps laid out in lines were checked once a day and the rodents captured were weighed and sexed, and individually toe-clipped. The type of sponge was noted (as S or N) and the piece then replaced by a fresh one of the same type. Noting the possibility that the scent on the pieces of sponge might prove volatile, the pieces were replaced every two days in traps in which no rodent had been caught.

\section{Experiment II}

To confirm the observations regarding the reactions of voles to the scents of $\mathrm{N}$ and $\mathrm{S}$, five sets of two live traps containing oats, apple and 3 pieces of sponge (as in the experiment I) were laid out in the field at distances from each other of $40 \mathrm{~m}$. On the following day, voles that had been captured were given further oats and moist food, while other species were released and the second trap in any given pair closed (if it was not occupied).

After the second day, the voles were released and all the live traps supplied with fresh bait and clean pieces of sponge before being reset. The sponges which were removed - considered to bear the scent of a neighbour - were placed in the centre of new Bristol board and of dimensions $32 \times 22 \mathrm{~cm}$. The same kind of board was prepared with the scent of stranger individuals. Two such pieces of board were placed at each capture point (about 2 meters from the trap). One bore the $\mathrm{N}$ scent and the other the $\mathrm{S}$ scent. The distance between the two pieces of board was 2 meters. The boards were exchanged once a day and, pencil-marks were made of the places where urine or faeces had been deposited.

The first two experiments confirmed that voles were more interested in the scent derived from neighbours than in that from unfamiliar individuals (see results). As a result, further research was carried out using two other methods, with a view to determining the range of spatial familiarity with the scent of neighbour individuals.

\section{Experiment III}

To answer the question concerning the distance from the place of capture of donor individuals across which their scent would be considered as $\mathrm{N}$ scent by others - and hence the distance beyond which the scent would be regarded as $\mathrm{S}$ scent - some 200 snap traps were laid out in the forest along a line $400 \mathrm{~m}$ long. The traps were placed singly at 2-metre intervals. Intersecting at the midpoint of the line (between traps 100 and 101) was a line of 10 live traps at right angles, again with traps placed at 2 -metre intervals. The voles caught here were brought to the laboratory (for 1 day only), in order that sponges with the scent of $\mathrm{N}$ might be prepared. To do this, the captured voles were placed in a 2-litre jar with about 110 pieces of sponge cut up in the same way as in the experiment I. The rodents in the jar were kept without food and water three times, each time for three hours, and there was a one-hour break during which the voles were transferred to a terrarium in which they obtained food and water ad libitum. The sponges with the S scent were prepared in the same way, using voles captured $40 \mathrm{~km}$ away and kept in the laboratory. Care was taken to ensure that the ratio of male to female voles was similar to that in the group used on a given day to prepare the local scent. Scented baits of the two kinds were then placed alternately in traps along the line, and replaced every two days; daily following a capture. Local individuals were released where they had been caught following the preparation of the baits.

\section{Experiment IV}

With the $200 \mathrm{~m}$ line having emerged as too short to designate the range limits of familiarity with the scent of a donor, an experiment IV was then run. In the field, 200 live traps were laid out in ten parallel lines $200 \mathrm{~m}$ apart (and given numbers 1-10). Each line had 20 such traps at points marked 1-20. The distance between traps was $5 \mathrm{~m}$ and oats were used as bait. The traps were checked once a day, in the morning, with the voles caught being collected together with the marked trap and taken to the laboratory. The traps removed were replaced by clean ones. The voles were weighed, sexed, checked for their reproductive condition and given a number. The scent of each individual rodent was 
then obtained, with the procedure being as with the line of 200 traps, except for the fact that each individual was placed in a separate quarter-liter jar with 10 pieces of sponge. The sponges thus given the scent of a defined donor were then placed in vials marked with the number of the donor and the date of collection of the scent. Vials with pieces of sponge were kept in a freezer in temperature $-20^{\circ} \mathrm{C}$ (Drickamer et al. 1992), but for not longer than 3 days. The hour before each test, the number of pieces required on the given day were removed and kept at room temperature.

All rodents from which scent had been obtained were next subjected to a test in which each was placed for 1 minute in a $1.5 \times 1.0 \times 0.8 \mathrm{~m}$ glass. The terrarium was in premises with low-intensity, diffuse artificial lighting. The voles were put in the same place half way along the short side of the terrarium and $10 \mathrm{~cm}$ from the wall. Placed on the opposite side, again $10 \mathrm{~cm}$ from it, was a line of pieces of sponge in pairs, with each pair at one of three permanent points. The extreme points were supplied with scented pieces of sponge (tested samples), while the central point had fresh pieces. The tests made use of tested samples of two donors caught at different distances from the place of origin of the tested individual (Table 2). Each vole was tested twice, with the same combination of scents deriving from definec donors. The first test was done between 20.00 and 23.00 and the second the following day between 07.00 and 10.00 .

The types of behaviour of the tested individuals that were treated (equally) as signs of interest in the scent of a donor were: an approach to a given piece of sponge, the sniffing of it, attempts to chew or move it, multiple approaches to one piece of sponge with a simultaneous lack of reaction to the remainder, and the release of urine or faeces in the vicinity of a piece.

After each test, the terrarium was cleaned with water plus detergent, before being dried in a stream of air. Tested samples were used once. All tests were performed by the same individual (the author.

The experiment was carried out in two periods: spring/summer and autumn.

As experiment IV tested the reactions of voles to a scent in laboratory conditions, an additional experinent $(\mathrm{V})$ was carried out to test in the field the reactions to scents from various places.

\section{Experiment V}

Pieces of Bristol board sponge, as in experiment II were laid out in the forest every $3 \mathrm{~m}$ along a line. Bcards held pieces of sponge bearing the scent of voles captured at distances of $200,400,600,800$, 1000,1200 and $1400 \mathrm{~m}$ from the line. Scents were imparted to the sponge, their origins noted and the pieces of sponge kept in the manner described for the experiment IV. Ten or 20 pieces of board with sponge bearing the scent of voles caught at each of the aforementioned distances were distributed along a line and exchanged each day, in the morning. Immediately after collection, the boards were checked for the presence or absence of rodent faeces, with presence (irrespective of the number of droppirgs) being denoted by a "+". The boards with faeces were then segregated in accordance with the disiance of origin of the donor of the scent on the piece of sponge.

\section{Results}

\section{Reactions of voles to the scents of neighbours and strangers}

\section{Experiment I}

Serenty-one percent of the 35 voles captured were taken in traps containing pieces of sponge bearing the scent of neighbour individuals. The mean daily capture rate for traps with the scent of a neighbour was $2.3 \pm 1.7$ individuals, compared with $0.9 \pm 09$ in the case of traps with the scent of a stranger. Comparison of means by Student $t$-test for linked pairs revealed the capture rate to be significantly higher wherebaiting was with the scents of neighbours as opposed to strangers $(p<0.02)$. 


\section{Experiment II}

A total of 90 pieces of board were laid out in the course of the experiment, and the pieces of board collected each day were divided into two groups: a) those with tested samples of $\mathrm{N}$ scent, and b) those with tested samples of S scent. The traces of urine were added together for each group, as were the traces of faeces (Table 1). Statistical analysis using the Student $t$-test for linked pairs revealed significantly more traces of both urine $(p<0.01)$ and faeces $(p<0.01)$ on the pieces of board which had held sponge with the scent of local voles.

Table 1. Number of individual traces of faeces and urine on pieces of board with centrally-located pieces of sponge bearing the scent of neighbour $(\mathrm{N})$ or stranger (S), on successive days of eksperiment II. Student $t$-test for linked pairs: $\mathrm{a}-t=3.96, s^{2}=24.53, p<0.01 ; \mathrm{b}-t=3.39, s^{2}=51.64, p<0.01$.

\begin{tabular}{|c|c|c|c|c|}
\hline \multirow{3}{*}{$\begin{array}{l}\text { Days of } \\
\text { experiment }\end{array}$} & \multicolumn{4}{|c|}{ Number of traces of faeces or urine on board with $\mathrm{N}$ or $\mathrm{S}$ scent } \\
\hline & \multicolumn{2}{|c|}{$\mathrm{N}$} & \multicolumn{2}{|c|}{$\mathrm{S}$} \\
\hline & Faeces & Urine & Faeces & Urine \\
\hline 1 & 28 & 29 & 24 & 29 \\
\hline 2 & 16 & 27 & 1 & 17 \\
\hline 3 & 8 & 15 & 4 & 7 \\
\hline 4 & 9 & 18 & 7 & 17 \\
\hline 5 & 13 & 9 & 6 & 8 \\
\hline 6 & 10 & 14 & 6 & 5 \\
\hline 7 & 15 & 28 & 6 & 9 \\
\hline 8 & 12 & 26 & 0 & 5 \\
\hline 9 & 36 & 28 & 20 & 22 \\
\hline Total & 147 & 194 & 88 & 119 \\
\hline Mean daily & $16.3 \pm 6.9^{\mathrm{a}}$ & $21.6 \pm 6.7^{\mathrm{b}}$ & $9.8 \pm 6.6^{\mathrm{a}}$ & $13.2 \pm 7.1^{\mathrm{b}}$ \\
\hline
\end{tabular}

The range of spatial familiarity with scent

Experiment III

Of the 103 voles in the experiment, 67 were captured at tested samples of $\mathrm{N}$ scent (mean $6.1 \pm 3.9$ individuals per day), and 36 at those with the scent of unfamiliar individuals (mean $3.3 \pm 2.3$ per day). Application of the Student $t$-test for linked pairs revealed a difference between these means that was significant at $p<$ 0.02 (Fig. 1).

A check was made to determine whether increasing distance from the places of capture of donors of the neighbour $(\mathrm{N})$ scent was associated with changes in the numbers of voles caught in snap traps. To this end, a straight-line regression was 


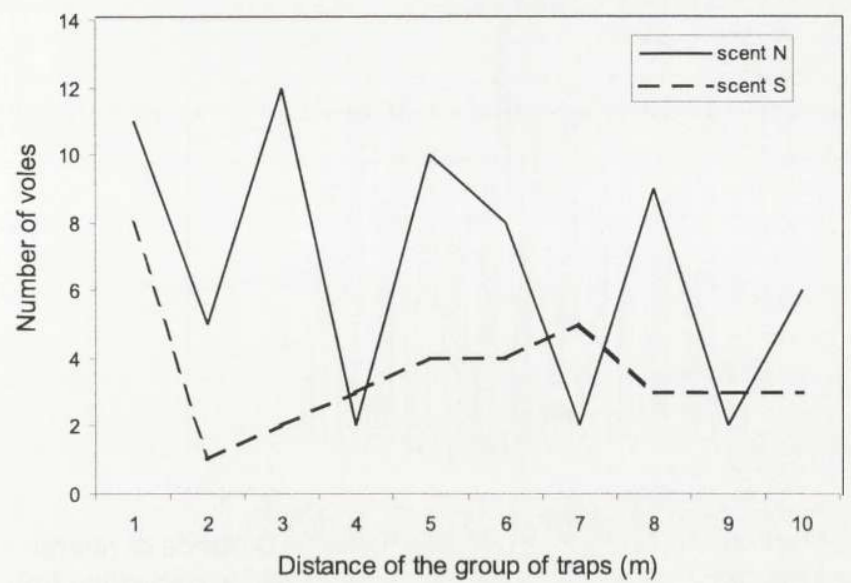

Fig. 1. Number of voles captured in traps with $\mathrm{N}$ or $\mathrm{S}$ scents on the line in experiment III. Traps were combined into groups of 10 with scent $\mathrm{N}$ or $\mathrm{S}$, and the place of origin of the donor was considered to be the distance of the most distant trap of the group.

determined for captured voles in successive traps with the scent of $\mathrm{N}$ or $\mathrm{S}$ donors. The two straight-line regressions $(y=9.47-0.02 x$ for the scent of neighbour donors and $y=4.26-0.01 x$ for the scent of stranger) were then compared using a test for differences in slope coefficients to see if they differed significantly. The obtained statistic $t=0.0548$ showed that the regressions did not differ significantly in their slope to the axis, indicating that interest in the two scents did not change with increasing distance from the place of origin of the donor of the scent across the entire $200 \mathrm{~m}$ of the line. Thus, in the whole experiment, a greater interest of rodents in the scent of neighbour individuals was maintained - as confirmed by the coefficients for the straight-line regression (9.47 and 4.26).

\section{Experiment IV}

Analysis with regard of sex

The experiment carried out in the spring/summer period was characterized by a preponderance of males among the voles captured, at $83 \%(n=254)$. In contrast, captures made in the course of the autumn experiment involved a 1:1 ratio of males to females (92 and 92, $n=184$ ).

A check was made as to whether males and females differed in their choice of the sex of the donor. Males were found to select the scents of females in $53 \%$ of cases ( $n$ $=188)$, with the figures for spring/summer and autumn being $51 \%(n=101)$ and $56 \%(n=87)$ respectively. Chi-square tests on these results showed no significant preferential selection of females, ie that the choices were random ones.

In turn, females were found to select the scent of males in 55\% of cases $(n=99)$, with the frequency in spring/summer being $70 \%(n=31)$ and that in autumn $48 \%$ $(n=68)$. In this case, chi-square tests did reveal the significantly more-frequent 


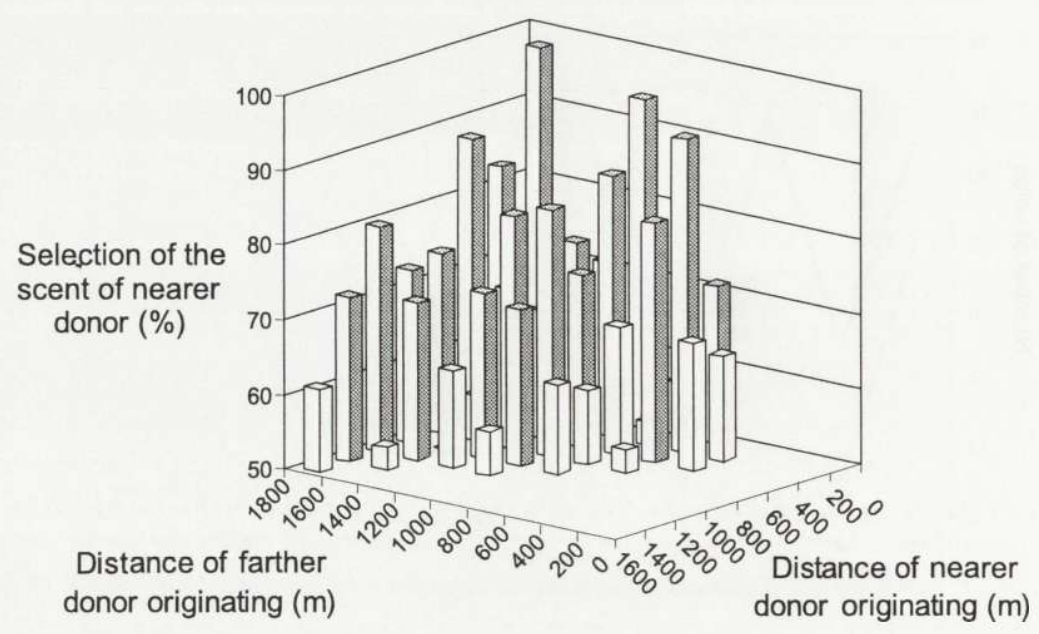

Fig. 2. Selection of pieces of sponge (\%) with the scent of a donor caught closer to the place of capture of the tested individual in experiment IV. The shaded column denotes selection of the scent of the nearer donor to a degree statistically different from random.

selection of the scent of males by females in the spring/summer period $\left(\chi^{2}=4.63, p\right.$ $<0.05$ ), though the preferences overall and for autumn were not significant.

Subject to further analysis were the tests in which a sexually-active female or male chose between the scent of a sexually-active male and a female. In these circumstances, females showed a significant preference for male scent $(61 \%, n=$ $46, \chi^{2}=4.65, p<0.05$ ), with the respective figures for spring/summer and autumn being random ( $73 \%$ of $n=26$ and $45 \%$ of $n=20$ ). In turn, males chose the scent of females in $58 \%$ of cases $(n=111)$ overall, in $54 \%$ of cases in spring/summer $(n=69)$ and in $68 \%$ of cases in autumn $(n=42)$. Only in the last cases did the differences indicate a significant preference for the scent of females $\left(\chi^{2}=4.02, p<0.05\right)$.

Chi-square tests also showed that selections were random where individuals chose between the scent of a male and a non-sexual active female.

Differences in olfactory preferences in relation to gender were also sought for the two periods of the experiment. Calculated to this end - separately for males and females - was the percentage selection for an individual deriving from a distance closer by at least $200 \mathrm{~m}$ (Fig. 2) to the tested individual. In the spring/summer period, females chose a piece of sponge with the scent of an individual from a shorter distance away random ( $54 \%$ of $n=69)$, while males made such a choice non-random ( $62 \%$ of $n=348, p<0.001)$. In autumn both sexes made such a choice non-random (females: $78 \%$ of $n=174, t=3.633, p<0.001$ and males: $80 \%$ of $n=$ $191, t=4.453, p<0.001$ ).

Of the females captured, $18 \%$ in spring/summer $(n=44)$ and $13 \%$ in autumn $(n$ $=92$ ) were sexually. This group of females was not found to differ significantly from the remainder where selection in relation to the distance of origin of the donor was concerned. 
Analysis with regard of age

The voles captured were assigned to one of two groups. These groups, termed A and $\mathrm{B}$, respectively included individuals weighing distinctly less or distinctly more than $17 \mathrm{~g}$, as no voles were found to have masses close to this particular value. In spring/summer, group A consisted of over-winterers and accounted for $95 \%$ of the sample $(n=254)$, while in autumn it accounted for only $42 \%$ of the individuals captured $(n=184)$.

The existence of these two groups made it necessary to determine whether body mass was in any way related to the choice of scent made. In spring/summer, $65 \%$ of the 386 choices involved over-winterers selecting - from the two tested samples on offer - the one smelling of an individual from nearer by. This figure differed significantly from the $50 \%$ expected with random selection (test of proportion, $t=$ $3.432, p<0.001$ ). In the same period, individuals from group B were found to make choices at random, although this may simply have reflected the small sample size ( $n$ $=43$ ).

In autumn, voles from both groups showed a clear preference for tested samples of a nearer individual. $78 \%$ of selections made by group A individuals were of this kind ( $n=149)$, as were $84 \%$ of the selections made by those in group B ( $n=196)$. Tests of proportion showed both of these preferences to be significant at $p<0.001$ (for $\mathrm{A}, t=4.650$, for $\mathrm{B}, t=8.333$ ). In addition, no differences were found between the groups in autumn in their selection of pieces of sponge with the scent of a "nearer" donor. These results point to a lack of body mass-related differences in the selection of the scents.

In the spring/summer period, there were 8 sexually-active females, of which all were members of group $\mathrm{A}$, thus accounting for $3 \%$ of the total $(n=240)$. In contrast, in autumn, $10 \%$ of group A was made up of sexually-active females ( $n=$ $77)$, in comparison with only $4 \%$ of group B $(n=107)$. As a consequence of such limited representation, it was not possible to uncover significant differences in the scent preferences of such individuals in either group.

The experiment included a total of $8 \%$ of cases (among $n=856$ ) in which the tested individual showed indecision in selecting one of the scents, as well as $2 \%$ in which a clean piece of sponge was chosen. In both cases, the preferences shown for these variants do not achieve statistical significance.

\section{Study for the range of olfactory familiarity}

An analysis seeking to define the limits of olfactory familiarity with a neighbour made use of 842 tests, and hence included cases in which no choice was made between tested samples of "nearer" and "farther" donors. Cases of the selection of clean pieces of sponge were however omitted.

Calculations were made of the percentage of selections of scent from the "nearer" donor in all possible combinations (Table 2). The test of proportion was then used to check if these percentage selections differed statistically from $50 \%$. All cases in which differences were not significant denoted random selections. In the 19 
Table 2. Selection of distances of origin of two donors of scent used in experiment IV. Numbers denote the number of tests carried out using donors from these two distances.

\begin{tabular}{|c|c|c|c|c|c|c|c|c|c|}
\hline \multirow{2}{*}{$\begin{array}{l}\text { Distance of farther } \\
\text { donor originating } \\
\text { (m) }\end{array}$} & \multicolumn{9}{|c|}{ Distance of nearer donor originating (m) } \\
\hline & 0 & 200 & 400 & 600 & 800 & 1000 & 1200 & 1400 & 1600 \\
\hline 200 & 43 & & & & & & & & \\
\hline 400 & 15 & 16 & & & & & & & \\
\hline 600 & 18 & 11 & 27 & & & & & & \\
\hline 800 & 14 & 13 & 17 & 15 & & & & & \\
\hline 1000 & 14 & 15 & 21 & 15 & 29 & & & & \\
\hline 1200 & 16 & 13 & 15 & 23 & 21 & 23 & & & \\
\hline 1400 & 7 & 16 & 21 & 16 & 18 & 30 & 26 & & \\
\hline 1600 & 13 & 11 & 13 & 16 & 27 & 24 & 18 & 17 & \\
\hline 1800 & 10 & 18 & 16 & 19 & 22 & 15 & 24 & 25 & 26 \\
\hline
\end{tabular}

cases, the voles more often chose the scent of the "nearer" donor (Fig. 2). Only when tested voles were offered a choice between the scents of donors caught $200 \mathrm{~m}$ from them or on the same line as them (referred to by convention as a distance of 0 $\mathrm{m}$ ) was the "farther" scent chosen significantly more frequently.

In the face of unfamiliarity with the range limits of a vole's olfactory recognition of the scent of a donor, there existed a theoretical possibility that the following three variant situations might arise in the selection of pairs of scents for each test (Table 3):

A) a vole chooses between the scents of two neighbours - random selection of the "nearer" donor,

B) a vole chooses between the scents of two strangers - random selection of the "nearer" donor,

C) a vole chooses between the scent of one neighbour and one stranger, non-random selection of the "nearer" donor.

In analyzing the results it was found that with the different theoretical distances for the range limits of olfactory familiarity in variants A, B and C, voles treated scents differing in terms of the distance of capture of their donors as familiar ones (Table 3).

In variant $\mathrm{A}$, the percentage of selections for the scent of a "nearer" donor increased for successive range limits of olfactory familiarity. Where the limits were at distances of $200 \mathrm{~m}$ and $400 \mathrm{~m}$, the tested individuals more often chose the scent of a donor from further away. Beginning with the range limit set at a distance of $600 \mathrm{~m}$, the voles selected the scent of a donor at random, perhaps denoting that both were equally well-known. The situation changed where the range limit was $1200 \mathrm{~m}$, as in this case voles selected the scent of the "nearer" donor more frequently (Table 3). 
Table 3. Precentage (\%) selection of scent of a nearer donor originating in different groups in experiment IV ( $n$-number of test in group). A, B, C-denote distances of origin of donors of the scent on test pieces of sponge. * - cases in which the selection of pieces of sponge bearing the scent of the farther captured donor was non-random $(p<0.02)$. ** - cases in which the selection of pieces of sponge bearing the scent of the nearer captured donor was non-random $(p<0.001)$.

\begin{tabular}{|c|c|c|c|c|c|c|c|}
\hline \multirow{2}{*}{$\begin{array}{l}\text { Combina- } \\
\text { tions }\end{array}$} & \multicolumn{7}{|c|}{ The variations of ranges of olfactory familiarity of donor (m) } \\
\hline & & 200 & 400 & 600 & 800 & 1000 & 1200 \\
\hline \multirow[t]{3}{*}{ A } & $\%:$ & $21^{*}$ & $32^{*}$ & 44 & 54 & 56 & $62^{* *}$ \\
\hline & $n:$ & 43 & 74 & 130 & 189 & 283 & 394 \\
\hline & $t:$ & 2.95 & 2.52 & & & & 3.42 \\
\hline \multirow[t]{3}{*}{ B } & $\%:$ & $65^{*}$ & $63^{* *}$ & $61^{* *}$ & $59^{* *}$ & 54 & 63 \\
\hline & $n:$ & 579 & 449 & 345 & 228 & 136 & 68 \\
\hline & $t:$ & 5.22 & 3.96 & 2.93 & 2.72 & & \\
\hline \multirow[t]{3}{*}{ C } & $\%:$ & $69^{* *}$ & $69^{* *}$ & $74^{* *}$ & $71^{* *}$ & $72^{* *}$ & $62^{* * *}$ \\
\hline & $n:$ & 220 & 31 & 367 & 425 & 423 & 380 \\
\hline & $t:$ & 4.14 & 4.88 & 6.9 & 7.33 & 6.73 & 3.17 \\
\hline
\end{tabular}

In variant $\mathrm{B}$, voles chose the scent of the "nearer" donor more frequently where the limits were set at $200 \mathrm{~m}$ up to $800 \mathrm{~m}$. Selections were again random for the remaining limits of 1000 and $1200 \mathrm{~m}$ (Table 3 ).

In variant $\mathrm{C}$, the scent of the "nearer" donor was chosen more frequently whatever the limit for the range of familiarity with the donor (Table 3).

The analysis done for these three variants showed that the clearest difference between the random selection of the scent of a donor in variants $\mathrm{A}$ and $\mathrm{B}$ and the significant preference for the scent of the "nearer" donor in C occurred for a theoretical range limit of $1000 \mathrm{~m}$. Nevertheless, this cannot be interpreted as a defined boundary, but rather points to the existence of a zone of declining interest of other voles in the scent of a donor from around $1000 \mathrm{~m}$ from the place where the donor of that scent lived.

\section{The range limit for olfactory familiarity in the field}

\section{Experiment V}

Rodent droppings were recorded on 140 of the 840 pieces of board laid out in the field. Their presence attested to interest shown by other individuals in the scent of the piece of sponge placed in the centre of the board. Analysis of traces of urine was made impossible by heavy rain during the experiment.

The boards marked with faeces were analyzed from the point of view of the distance of the place of capture of the donor of the scent on the sponge from the place where the board was laid. The proportion of the boards with traces of faeces 


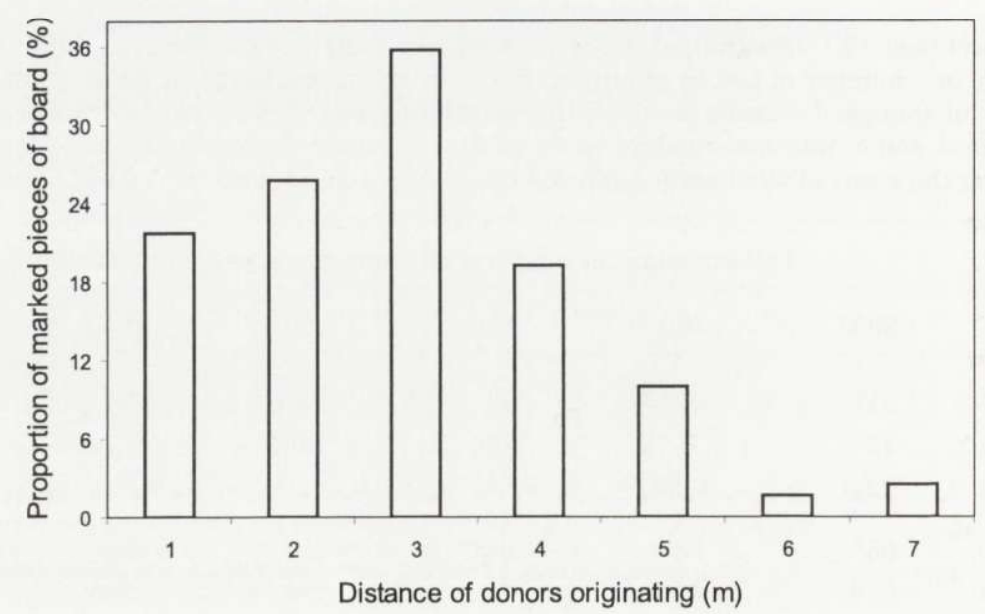

Fig. 3. Proportion of pieces of board marked with faeces in experiment V. 120 pieces of board were laid out at the time with scents of donors originating from each of seven different distances away ( from 200 to $1400 \mathrm{~m}$ ).

was calculated in relation to the 120 laid out to represent each of the seven distances of origin of donors (Fig. 3).

Checks were made to determine whether there were differences in the daily means for the number of marked boards bearing the scents of donors originating from each of the 7 distances. Analysis of variance confirmed the existence of such differences $(F=8.045, p<0.001)$, as well as the significant difference of mean numbers of marked boards for distances of origin of donors equal to 1200 and 1400 $\mathrm{m}$ in relation to the other tested distances.

A chi-square test was used to determine if the numbers of marked boards for different distances of origin of donors could be combined into homogenous groups, in accordance with the suggestion resulting from the previous analysis. The following groups were confirmed:

I - for the first 4 distances to the place of origin of the donor of a scent (200-800 $\mathrm{m}$ inclusive), the chi-square test was significant at $p<0.05$, thus pointing to the similar attractiveness to visiting voles of the scent of donors originating from distances within this range.

II - for the distances 1200 and $1400 \mathrm{~m}$ from the place of origin of the donor of a scent, the chi-square test was again significant at $p<0.05$, indicating that these scents were also similarly attractive to visiting rodents, albeit less attractive than those of group I.

Checks were made for the existence of a correlation between the distance of the place of origin of a donor and the number of marked boards. A statistically significant inverse correlation was obtained $(r=-0.58, p<0.05)$. The straight-line regression obtained was characterized by the equation $y=5.23-0.70 x$ (Fig. 4). 


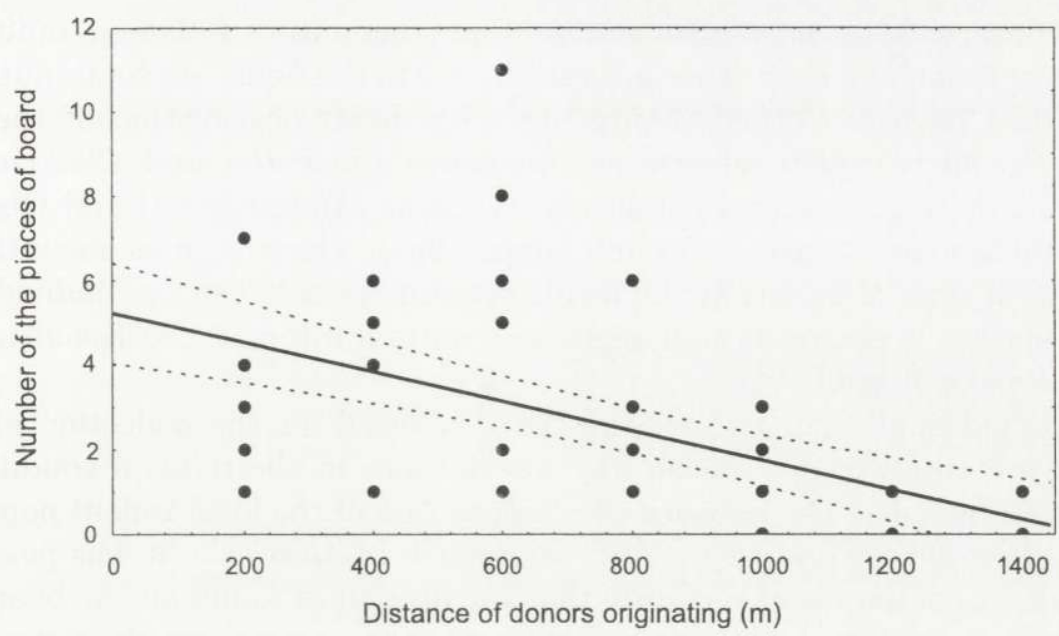

Fig. 4. Number of pieces of board with traces of rodent faeces of the 7 different distances for the places of origin of scent donors in experiment V. Regression $y=5.23-0.70 x, r=-0.58$.

\section{Discussion}

It results from observations of the behaviour of white-footed mice Peromyscus leucopus noveboracensis and deer mice $P$. maniculatus ozarkiarum in a circular arena (Vestal and Hellack 1978), that individuals of these species more willingly approached a neighbour (caught up to $40 \mathrm{~m}$ from the tested individual) than a stranger (caught more than $200 \mathrm{~m}$ from it). In turn, in comparison with individuals unknown to each other, neighbour individuals of $P$. leucopus were less aggressive towards each other, avoided mutual contacts less often and sought each other out more often. Similar results were obtained in field experiments (Kołodziej et al. 1972, Rajska-Jurgiel 1976) in which traps were "baited" with a live vole. Individuals came up to such traps more willingly where the rodents inside were from the neighbourhood of the trap, rather than outsiders. It emerged that the least attractive to all voles were adult females and individuals with high capture rates and large ranges. On the other hand, a sexually-active individual more often sought contacts with sexually-active individuals of the opposite sex, while a non-sexually-active vole more often came up to traps containing other non-active individuals.

The use of pieces of sponge scented by neighbours or strangers (Andrzejewski and Owadowska 1994) as bait in traps supported the hypothesis that differences in the reactions of voles to the scents of $\mathrm{N}$ and $\mathrm{S}$ individuals.

The different behaviour of rodents as they encountered the scent of a stranger in experiment II may indicate that voles may explore it as a lovely scent. Such behaviour may suggest that the information borne by scent is very "readable", allowing for olfactory recognition of the individuals occupying a defined area. It may also attest to joint conditioning of space by voles. 
These observations may also denote that encounters between individuals completely unknown to each other are rather rare in the field. As some authors in the literature have concerned themselves with direct observation of the social behaviour of such rodent species as Apodemus flavicollis and Clethrionomys glareolus in the more natural conditions of forest (Andrzejewski and Olszewski 1963) or enclosures (Garson 1975 and Gipps 1981). These studies show that the most frequent type of behaviour following encounters between two individuals of the same species is escape or non-aggressive mutual interest also Kołodziej et al. 1972 and Rajska-Jurgiel 1976.

The method applied in the experiment II allowed for the collection of information on rodents without almost any interference in the natural conditions of their lives (Johnson 1974). Because the composition of the local rodent population had been observed for five years (Andrzejewski et al. in press), it was possible to accept with a high degree of certainty that the droppings found on the board were from voles: other rodent species were only found to appear very rarely in the area.

Experiment V showed that the rodents studied more often came up to places bearing the scents of donors living closer by (Fig. 4). Boards with tested samples of donors from more than $1000 \mathrm{~m}$ away were visited only sporadically. The interest shown by voles in the boards was greater where the scents present were of individuals from between 200 and $600 \mathrm{~m}$ away (Fig. 3), but was lower where other distances were involved.

The phenomenon of long-distance movements by wild-living populations of different rodents is well known, eg Crawley (1969), Andrzejewski and Babińska-Werka (1986), Liro and Szacki (1987), Tew (1988), Dickman and Doncaster (1989), Szacki and Liro (1991), Szacki et al. (1993), Dickman et al. (1995). These studies all show that long-distance movements of rodents that are related to the species involved, eg: voles about $500 \mathrm{~m}$ (Dickman and Doncaster 1989), yellow-necked mice females $800 \mathrm{~m}$ and males $1000 \mathrm{~m}$ (Wolton 1985), wood mice (Apodemus sylvaticus) up to $2500 \mathrm{~m}$ (Tew 1988) and field mice (A. agrarius) more than $1000 \mathrm{~m}$ (Szacki and Liro 1991). This information corresponds with the sizes of areas covered by rodents and requiring effective scent-marking. They may take the form of a network of corridors (Szacki et al. 1993), which allow rodents long-distance, and if necessary rapid, transit through areas covered by vegetation and other obstacles hindering visibility in the field. Many workers (eg Mazurkiewicz 1983, Wolton and Flowerdew 1985, Grüm 1988) have proposed distances of movements of $100 \mathrm{~m}$ that result from the noted ranges for species, but these would seem to be much too low.

Experiment III showed that the scent of a donor was treated as equally as that of a neighbour at distances of up to $200 \mathrm{~m}$ from its place of residence (Figs 1 and 3). Along the entire length of the line there was no place from which the scent of a neighbour individual was less interesting to the voles.

In the light of the above, experiment IV was run to establish just how far (beyond $200 \mathrm{~m}$ from a place of residence) the scent of a donor was known in the field. The results indicated a decline in a vole's interest in the scent of a donor from 
about $1000 \mathrm{~m}$ away from its place of origin. This in turn indicated that two voles knew each other's scents in cases where the distances between their places of capture did not exceed $1000 \mathrm{~m}$. It would obviously be a mistake to treat this distance as the distance of field movements among the rodents, for it cannot be said that the place of capture of a vole is equivalent to its place of residence, since a live trap may catch individuals coming to it even from far away. Thus the real distance between the places of habitation of two captured rodents is different to (either greater or smaller than) the distance between their places of capture. However, geometric analysis of a case in which two voles caught about $1000 \mathrm{~m}$ from each other knew each other's scents, allowed for the minimum distance of their movements to be determined - at $250 \mathrm{~m}$. The case in question would involve voles living less than $1000 \mathrm{~m}$ apart, while their places of capture are found at opposite extreme ends of the area penetrated by them.

Since the scent left by a rodent on a piece of sponge is of defined peristence (eg 2 days, Andrzejewski and Owadowska 1994), it may be presumed that the covering by voles of distances greater than $250 \mathrm{~m}$ cannot be a rare phenomenon and cannot be associated with the taking of a decision to migrate. Also difficult to accept is the claim that movements of these kinds are linked with a necessity to mark territory in order to define territorial boundaries.

No differences were found between the spring/summer and autumn periods where the selection of the scent of individuals deriving from different distances was concerned. This finding entitles one to suggest that the changes in the sizes and locations of rodents' home ranges described by Mazurkiewicz (1971), Bujalska (1985a, b), Gliwicz (1988) and Koskela et al. (1997) may also result from the large distances they cover. The introduction of an artificial source of food to the natural spatial system of a rodent - for example a dense network of live traps - may lead to a situation in which individuals having a good food base close at hand reduce the distances they travel (eg Andrzejewski and Dominas 1963, Wolton and Flowerdew 1985). In this context, the non-utilization in fieldwork of a food bait (Andrzejewski and Owadowska 1994) may combine with the ease with which scent can be transferred to a trap (using pieces of sponge) to provide a method which ensures the avoidance of similar errors. The experiments done were able to confirm the supposition already known in the literature (Montgomery 1979, Tew et al. 1994) that voles of the two sexes do not differ in their selection of the scent of a donor.

Experiment IV revealed no differences in the selection of the distance of origin of the donor of a scent in relation to the body masses of the voles tested (assigned to groups $\mathrm{A}$ and $\mathrm{B}$ ). This indicates that all individuals in the population knew the scents of neighbours at a similar distance from their places of habitation. These observations differ from those in the literature and deriving mainly from laboratory experiments carried out for example on reared populations of house mice (eg Carr et al. 1970). Field experiments done by Heske (1987) on a wild population of California voles Microtus californicus confirmed that the reactions of individuals of this species to the scents of other rodents were dependent on the age of the donor. 
Observations made in the laboratory (Petrusewicz 1957, Petrusewicz and Wilska 1959, Healey 1967) show that the most common behaviour among rodents reared or just held there involved aggressive attacks. The manifestation of aggressive behaviour between voles is also a phenomenon in territorial defense noted by Bujalska (1973, 1985a, b, 1992) in the course of the breeding season. According to the author, such behaviour constitutes the basis of social organization in a population of voles and leads to the rejection of a hypothesis concerning reproduction and increases in abundance that are density-dependent.

The results of the experiments presented here show that the phenomenon of aggression directed towards another individual (beginning with neighbours) may not be widespread. The work provides evidence for the positive reactions of voles to the scent of a neighbour and for the avoidance of the scent of an unknown individual. These reactions differ from the initially-anticipated increased aggression towards others with greater distances between places of origin.

Acnowledgements: I would like to thank Professor R. Andrzejewski for his advice and support, Professors J. Gliwicz and Z. Pucek for reading earlier versions of this paper.

My sincere thanks go to Agnieszka Malina for help in running experiment II.

\section{References}

Andrzejewski R. and Babińska-Werka J. 1986. Bank vole populations: are their densities really high and individual home range small? Acta Theriologica 31: 409-422.

Andrzejewski R. and Dominas H. 1963. Niektóre problemy intensyfikacji metodyki ekologicznej. Ekologia Polska 9: 291-293.

Andrzejewski R. and Olszewski J. 1963. Social behaviour and interspecific relations in Apodemus flavicollis (Melchior, 1834) and Clethrionomys glareolus (Schreber, 1780). Acta Theriologica 7: $155-168$

Andrzejewski R. and Owadowska E. 1994. Use of odour bait to catch bank voles. Acta Theriologica 39: 221-225.

Andrzejewski R., Babińska-Werka J., Liro A., Owadowska E. and Szacki J. Drobne ssaki terenów zalesianych Kampinoskiego Parku Narodowego. Parki Narodowe i Rezerwaty Przyrody (in press).

Andrzejewski R., Babińska-Werka J., Liro A., Owadowska E. and Szacki J. 1997. The attractiveness of conspecific and interspecific odor for bank voles Clethrionomys glareolus. Acta Theriologica 42: 231-234.

Bujalska G. 1970. Reproduction stabilising elements in a island population of Clethrionomys glareolus (Schreber, 1780). Acta Theriologica 15: 381-412.

Bujalska G. 1973. The role of spacing behaviour among females in the regulation of the reproduction in the bank vole. Journal of Reproduction and Fertility, Suppl. 19: 463-472.

Bujalska G. 1985a. Fluctuations in a island bank vole population in the light of the study on its organization. Acta Theriologica 30: 3-49.

Bujalska G. 1985b. Regulation of female maturation in Clethrionomys species, with special reference to an island population of Clethrionomys glareolus. Annales Zoologici Fennici 22: 331-342

Bujalska G. 1992. Territoriality in the bank vole, its origin and some consequences. Viadomości Ekologiczne 38: 3-11. [In Polish with English summary]

Carr W., Mortorano R. and Krames L. 1970. Responses of mice to odours associated with stress. Journal of Comparative and Physiological Psychology 62: 336-338.

Chitty D. 1958. Self-regulation of numbers through changes in viability. Cold Spring Harbour Symposium of Quantitative Biology 22: 277-280. 
Christian J. J. 1950. The adreno-pituitary system and population cycles in mammals. Journal of Mammalogy 31: 247-259.

Crawley M. C. 1969. Movements and home ranges of Clethrionomys glareolus Schreber and Apodemus sylvaticus L. in north-eastern England. Oikos 20: 310-319.

Dickman C. R. and Doncaster C. P. 1989. The ecology of small mammals in urban habitats. II Demography and dispersal. Journal of Animal Ecology 58: 119-127.

Dickman C. R., Predavec M. and Downey F. J. 1995. Long-range movements of small mammals in arid Australia: implications for land management. Journal of Arid Environment 31: 441-452.

Drickamer L., Mikesic D. and Shaffer K. 1992. Use of odor baits in traps to test reactions to intra- and interspecific chemical cues in house mice living in outdoor enclosures. Journal of Chemical Ecology 18: $2223-2250$

Ferkin M. H., Sorokin E. S., Johnston R. E. and Lee C. J. 1997. Attractiveness of scents varies with protein concent of the diet in meadow voles. Animal Behaviour 53: 133-141.

Garson P. J. 1975. Social interactions of wood mice (Aptdemus sylvaticus) studied by direct observation in the wild. Journal of Zoology, London 177: 496-500.

Gipps J. H. W. 1981. Behawior of bank voles, Clethrionomys glareolus, in the field. Journal of Mammalogy 62: 382-384.

Gliwicz J. 1988. Seasonal dispersal in non-cyclic populations of Clethrionomys glareolus and Apodemus flavicollis. Acta Theriologica 33: 263-272.

Griffiths J. and Kendall M. D. 1980a. The structure of the glands in the angulus oris of the bank vole Clethrinomys glareolus. Journal of Zoology 192: 311-322.

Griffiths J. and Kendall M. D. 1980b. Structure of the plantar sweat glands of the bank vole Clethrionomys glareolus. Journal of Zoology 191: 1-10.

Grüm L. 1988. On "the home range" concept and principles of comparability of its aspect estimates. Wiadomości Ekologiczne 34: 61-71. [In Polish with English summary]

Healey M. C. 1967. Aggression and self-regulation of population size in deer mice. Ecology 48: 377-392.

Heske E. 1987. Responses of a population of California voles, Microtus californicus to odor - baited traps. Journal of Mammalogy 68: 64-72.

Johnson R. P. 1974. Scent marking with urine in two races of the bank vole (Clethrionomys glareolus). Behaviour 55: 81-93.

Kapusta J., Marchlewska-Koj A., Olejniczak P. and Kruczek M. 1996. Removal of the olfactory system modifies male bank vole behaviour in the presence of females. Behavioural Processes 37: 39-45.

Kołodziej A., Pomianowska I. and Rajska E. 1972. Differentiation of contact between specimens in Clethrionomys glareolus population. Bulletin de l'Academi Polonaise des Sciences 20: 97-101.

Koskela E., Mappes T. and Ylonen H. 1997. Territorial behaviour and reproductive success of bank voles Clethrionomys glareolus females. Journal of Animal Ecology 66: 341-349.

Kruczek M. 1994. Reactions of female bank voles Clethrionomys glareolus to male chemosignals. Acta Theriologica 39: 249-255.

Kruczek M. 1997. Male rank an female choice in the bank vole, Clethrionomys glareolus. Behavioural Processes 40: 171-176.

Lenington S. 1994. Of mice, men and the MHC. Trends in Ecology and Evolution 9: 455-456.

Liro A. and Szacki J. 1987. Movements of field mice Apodemus agrarius (Pallas) in a suburban mosaic of habitats. Oecologia 74: 438-440.

Marchlewska-Koj A., Kruczek M. and Toch E. 1983. Suppression of estrus cycle of female mice by ovariectomized females. Hormone and Behaviour 17: 233-236.

Marchlewska-Koj A., Kruczek M. and Zacharczuk-Kakietek M. 1992. Olfactory signals of conspecifics stimulate adrenal function in male mice. [In: Chemical signals in vertebrates VI. R. L. Doty and D. Müller-Schwarze, eds]. Plenum Press, New York: 271-276.

Mazurkiewicz M. 1971. Shape, size and distribution of home ranges of Clethrionomys glareolus (Schreber, 1780). Acta Theriologica 2: 23-60.

Mazurkiewicz M. 1983. Spatial organization of the population. Acta Theriologica 28, Suppl. 1: 117-127. 
Mazurkiewicz M. 1994. Factors influencing the distribution of the bank vole in forest habitats. Acta Theriologica 39: 113-126

Montgomery W. 1979. An examination of interspecific sexual and individual biases affecting rodent captures in Longworth traps. Acta Theriologica 24: 35-45.

Petrusewicz K. 1957. Investigation of experimentally induced population growth. Ekologia Polska A 5: 281-309.

Petrusewicz K. and Wilska T. 1959. Investigation of influence of inter-population relations on the result of fights between male mice. Ekologia Polska A 7: 359-390

Pucek M. 1983. Ecology of the bank vole. Habitat preference. Acta Theriologica 28, Suppl. 1: 31-40.

Quay W. B. 1962. Apocrine sweat glands in the angulus oris of microtine rodents. Journal of Mammalogy 43: 303-310.

Quay W. B. 1968. The specialised posterolateral sebaceous glandular regions in microtine rodents. Journal of Mammalogy 49: 427-445.

Rajska-Jurgiel E. 1976. Interactions between individuals of a population of the bank vole, Clethrionomys glareolus (Schreber, 1780). Ekologia Polska 24: 3-35.

Solon J. 1995. Roślinność rzeczywista i potencjalna. Operat ochrony ekosystemów lodowych oraz wybranych elementów flory. Plan Ochrony Kampinoskiego Parku Narodowego. Narodowy Fundusz Ochrony Środowiska, Warszawa: 1-105.

Stoddart M. D. 1980. The ecology of vertebrate olfaction. Chapman and Hall, London and NY: 1-231.

Stoddart M. D. 1974. The role of odor in the social biology of small mammals. [In: Pheromones. M. C. Birch, ed]. North-Holland Publisher Company, Amsterdam, London: 297-315.

Szacki J. and Liro A. 1991. Movements of small mammals in the heterogenous landscape. Landscape Ecology 5: 219-224.

Szacki J., Babinska-Werka J. and Liro A. 1993. The influence of landscape spatial structure on small mammal movements. Acta Theriologica 38: 113-123.

Tew T. 1988. The ecology of the European wood mouse (Apodemus sylvaticus) on British farmland. Proceedings of the Second International Behavioural Ecology Conference, Vancouver: 103.

Tew T., Todd I. and Macdonald D. 1994. Temporal changes in olfactory preference in murid rodents revealed by live-trapping. Journal of Mammalogy 75: 750-756.

Vestal B. M. and Hellack J. J. 1978. Comparison of neighbor recognition in two species of deer mice (Peromyscus). Journal of Mammalogy 59: 339-346.

Wilson E. O. 1975. Sociobiology. Belknap Press of Harvard University Press, Cambridge, Massachusetts: $1-697$.

Wolton R. J. 1985. The ranging and nesting behaviour of wood mice, Apodemus sylvaticus, (Rodentia, Muridae). Journal of Zoology, London 206: 203-224.

Wolton R. J. and Flowerdew R. J. 1985. Spatial distribution and movements of wood mice, yellow-necked mice and bank voles. Symposia of Zoological Society of London 55: 249-275.

Received 1 September 1997, accepted 17 March 1999. 